\title{
Divine Violence: The Ethics and Aesthetics of the Goddess-woman in the Abused Goddess Ad Campaign
}

\author{
Nkoyo Edoho-Eket \\ University of Wisconsin-Madison \\ edohoeket@wisc.edu
}

\begin{abstract}
In the fall of 2013, an ad campaign from the Mumbai-based agency Taproot exploded in popularity on social media and was featured on a variety of news sites, particularly in India and the United States. The campaign, known as the Abused Goddess ads, depicted an iteration of the Goddess most accurately characterized as a Goddess-woman, a divine-human hybrid figure possessing both the divine power of shakti and the vulnerability of human women. Stylized in the "canonical" images of the Goddesses Lakshmi, Saraswati, and Durga, the Goddess-women were shown as bruised victims of domestic violence. The Abused Goddess ads precipitated and codified the contemporary depictions of the Goddess-woman whose later iterations appear in the work of numerous digital artists. In particular, the ads exemplify an aesthetic that harnesses the power of shame and the mingling of gazes to further a secular-humanist ethic at the expense of devotional experience.
\end{abstract}

\section{Keywords}

Hinduism - shakti - Hindu goddess - darshan - visual culture - gaze theory - affect theory - shame - Mahādevī

Since the post-Independence women's movement began in India in the 1970s, the visual culture of South Asia has seen the proliferation of images of an ambiguous divine-human figure that embodies a contemporary interpretation of shakti. This hybrid figure, the Goddess-woman, can be seen in a diverse range of 
media, from comics and grassroots feminist posters to contemporary art. ${ }^{1}$ This figure departs from established models of women's ontological relationship with Mahādevī or, the Goddess, that underscored women's potential to become the Goddess, taking on divine qualities in order to redress a disruption of dhar$m a$. Such women are powerful, having their human powerlessness temporarily suspended in order to allow the Goddess to manifest her full powers. Instead, in images of the semi-divine Goddess-woman, the feminist construction of shakti conflates the cosmos-animating power of the Goddess and the socioeconomic status of human women, considering them to be interchangeable.

Although this variation of shakti is recent, evidence for the empowering potential of shakti has long since been noted in some Brahmanical traditions (Erndl, 2000, p. 93). Further, within some Tantric traditions shakti, and the feminine in general, are assigned a much less ambiguous position than in Brahmanical Hinduism. As Madhu Khanna notes, within Shakta Tantra shakti is envisioned as an intrinsic part of womanhood, divine and human (Khanna, 2002, p. 44).

While the concept of shakti has experienced a wide range of positions, valuations, and definitions over time, it should be noted that the general concept of shakti as the divine feminine power that animates the cosmos is widely understood and accepted among Hindus, even those outside of Shakta or Tantric traditions. Still, the degree to which human women are associated with shakti, or shakti is interpreted as feminist is highly variable. As Rita Gross has argued regarding the Goddess, she is neither feminist nor un-feminist since she is constructed via her relationships with humans (2000). Therefore, shakti is feminist, Gross argues, to the extent that it provides psychological comfort to women as an exaltation of the feminine in an overwhelmingly patriarchal network of religious symbols, not as an instrument for establishing equal rights for women (Gross, 2000, p. 107). Nevertheless, that women have a close and unique relationship with shakti is widely accepted, and it is this precise relationship to power that must be controlled via the subordination of women (Erndl, 2000, p. 95). Contemporary understandings of shakti share the theological preoccupation with the restoration of order but depart from traditional interpretations by regarding it explicitly as a tool to reorder the social world to achieve gender equality.

1 I have previously discussed representations of the Goddess-woman depicted in activist posters found in the Poster Women and Olakh Archives and in the digital art from Samyukta Madhu and Priyanka Paul in Edoho-Eket, 2016 and Edoho-Eket, 2018, respectively. 
Crucially, the shakti of the Goddess-woman is not merely the power of an exalted feminine principle. In images of the Goddess-woman it is not women's innate power that is emphasized, but the Goddess's vulnerabilities. As such, the figure is emphatically a Goddess with mundane qualities rather than a woman with superhuman ones. Consequently, the relationship to power is inverted, making women's powerlessness and human vulnerability a key feature of the figure that is featured in the Abused Goddess campaign. The ads, a lurid synthesis of religious imagery and violence, provide a striking example of the ethics and aesthetics of the Goddess-woman image, highlighting a new representation of womanhood that has become increasingly prominent in visual culture.

The Abused Goddess ad campaign became widely available to the public in September 2013 via the burgeoning Indian news-oriented site ScoopWhoop. Though circulated online as a print ad made by an Indian ad agency, the images found a much more widespread audience on the news-oriented US websites Buzzfeed and the Huffington Post, where write-ups about the images attracted over a million views that readers commented on, liked, shared, and tweeted in a matter of days. The images resonated with commenters who appreciated the depiction of "traditional" goddesses as vulnerable and susceptible to violence and applauded the ads for highlighting the ostensible hypocrisy of exalting Goddesses in a nation with such high rates of violence against women.

Purportedly a campaign for Save Our Sisters, the anti-human trafficking initiative from Save the Children India, the three ads depicted the immediately recognizable forms of Durga, Lakshmi, and Saraswati in replications of iconic images. The ads displayed three women dressed as forms of the Goddess stylized through props, paint, and photoshopped effects to resemble the popular form of devotional images typically categorized as calendar art (Figures 1-3). In place of their usually serene expressions, the three Goddesses were instead bruised and crying. The ads were accompanied by the text that exhorts the viewer, "Pray that we never see this day. Today, more than $68 \%$ of women in India are victims of domestic violence. Tomorrow, it seems like no woman shall be spared. Not even the ones we pray to" (Coloribus, 2013).

The sudden appearance of the ads prompted a mix of reactions from their international audience. While initially heralded by Buzzfeed and the Huffington Post as a bold attempt to stop violence against women, critics along the 
political spectrum regarded the ads as a failure. Conservative Hindu groups were aghast at the public desecration of a religious image, while leftist critics regarded the campaign as yet another reductive and sensationalistic depiction of helpless women in a long history of paternalistic constructions of Asian womanhood (“Abused Goddesses," World Religion News, 2013; Jha, 2013).

The variety of perspectives offered by critics along the political spectrum highlight the intense anxiety surrounding gender-based violence post-2012, following the highly-publicized gang rape and death of Jyoti Singh Pandey. Further, they offer insight into how the relationship between human women and the Goddess was transformed in response to emergent perspectives on gender-based violence. In the ads, the Goddess-woman elides the boundaries between devotional imperatives and the appeal for human rights, fostering a deliberate tension within the image and producing an unintentional permeability between secular and devotional ways of seeing. The ads attempt to mediate this confluence of gazes with both nods to, and a subsequent retreat from, aesthetic convention. In doing so, the Abused Goddess campaign indexes the transcultural significance of the Goddess-woman as evidenced by the ads' viral circulation on the Internet. The ads transform conventional understandings of shakti and its relationship to the Goddess by utilizing the affect of shame as a tool to shepherd the images from a theological discourse of devotional and reciprocal seeing to an aesthetic of secular human rights. In doing so, the images engage with and promote new categories of seeing by displacing the act of darshan with juridical models of viewership.

The Abused Goddess ads rely on a playful engagement with "canonical" idioms of divinity. Buzzfeed, for example, placed a great deal of emphasis on the "traditional" style of the paintings and was captivated by the painstaking detail that evoked the "old" or "authentic" (Jha, 2013). The ad-makers themselves address this tension in the less prominent text at the bottom of each ad:

The campaign execution comprised of a unique blend of the old style hand painted Indian art with modern photography, by recreating every aspect of the original posters from scratch. Everything from the background to foreground elements were either real or created and painted on, keeping the light and shadow in mind to make it look of that era. Props like the tree, swan, lotus, peacock, instruments etc. to finer elements like the drapery, jewelry, skin tones were made to match the style. 
All of which was then shot in the form of a single picture, breathing fresh life into an age old art form and yet creating a completely new visual experience to bring out a strong message" (Taproot India via Buzzfeed, 2013).

In this context, the "authentic" acts as a rhetorical device that aids in the campaign's implicit reordering of the hierarchy of value in favor of a secular humanist ethic. It is a reordering that signals the supplanting of the devotional viewing experience and the disruption of the divine gaze. The Abused Goddess ads wager their existence on the uncanny gap between their almost-being objects of devotion, and their coy rejection of religious coherence to serve as a public service announcement.

It is unsurprising that the images' appeal to the authority of the "authentic" is done via the meticulous replication of images first created by renowned painter Raja Ravi Varma (1848-1906). Ravi Varma utilized naturalistic styles of painting, combining European realism with Hindu religious figures. Varma's merging of human and divine forms was unprecedented not only in terms of stylistic convention, but also in its transformation of social and political space. This new hybridized realm of divine-human images is what Christopher Pinney has called the space of "magical realist mytho-politics," in which realism elides the distinctions between the "mythic" and the "historical" (Pinney, 2004, pp. 66-70). This foray into realism not only had enormous implications for the construction of Indian and Hindu womanhood, but it also saw the consolidation of the human and the divine into a singular body suitable for devotion - a body to be produced, reproduced, disseminated, seen, and imbibed. Varma's paintings then are not only integral to the formation of the collective imagination of what the deities look like, but also to what constitutes an authentic representation. Therefore, the explicit invocation of Ravi Varma in the Abused Goddess ads is meant to recall images so ubiquitous as to require no introduction. It is therefore not the lapse in distance between the woman and the Goddess that is so novel in the ads, but the jarring collapse of the powerful/auspicious with the vulnerable/injured.

However, such appeals to the images' "authenticity" combined with the ambiguity of the abusive act raise unsettling questions when the images are taken to their furthest theological extent. Even though the images turn the abusive event into one of stoic enduring, it is an event whose time has already passed, the violence of which is already encountered and made visible on the bodies of the three women-Goddesses. That the violent act itself is only gestured to via special effect helps mitigate the uneasiness that comes from the merging of the divine and the human. 
While Taproot is hardly the first to use subversive religious imagery to address issues of social justice, the images' viral circulation and their global audience create a new aesthetic that dwells on the abject state of Indian womanhood through the mortalization (and desecration) of the divine feminine. This resulting new way of seeing reconstructs the religious image through the ethics of secular humanist rights. This is achieved through the utilization of what Laura Mulvey (1975) has called "gaze mechanisms." In the context of the Abused Goddess ads, these can be assessed as the gaze of darshan, the gaze of the camera, and the gaze of the viewer. ${ }^{2}$

Diana Eck's Darśan (1998) provides a useful understanding of the concept of divine seeing with which to contrast the darshanic gaze mechanism present in the Abused Goddess ads. Eck's exegesis of darshan understands it as the "auspicious sight" of the divine in which an image of a deity is not merely a visual representation, but is the deity him- or herself (p. 3). Darshan is a multifaceted bilateral interaction between deity and devotee that is not simply a passive reception of visual data. Rather, darshan is a form of contact between deity and devotee that extends beyond the visual; seeing, in this context, is not only a form of touching, but also a form of knowing (p. 9). To see and be seen by the divine is to acknowledge and apprehend the "truth" of the divine and the devotee - that the devotee is the divine - and to then dissolve the barrier between them.

This is a distinct contrast between the darshanic gaze at work in the Abused Goddess ads, which gesture towards, but does not activate, the experience of darshan. The relationship between devotee and deity is not that of two subjects beholding one another and dissolving the perceived distance between them, rather it is an active subject (the viewer-devotee) beholding a passive object (the image of the Goddess). This representation of the Goddess is inert both as an image lacking ritual power and as a brutalized Goddess lacking the power to defend herself. Therefore, the primary distinction between the ritual concept of darshan and the darshanic gaze mechanism is predicated on the relationship between deity and viewer. The desacralizing violence depicted in the ads disrupts the visual contact that occurs within darshan, rendering the images ritually ineffectual.

2 I depart from Mulvey's schema by including darshan as a gaze mechanism, as opposed to characters in film, as Mulvey does. I am interested in analyzing darshan as a gaze mechanism for similar reasons as Coorlawala (1996) — to offer a variation on a Eurocentric model of gaze theory. 
Although the relationship between deity and beholder is distinct, darshan and the darshanic gaze mechanism share in common a fundamental relationship to the transformative potential of images. Eck, citing Jan Gonda (1969), states that "visual images are not data to be transformed by the mind, they are the bearers of thought" (p. 9). The "world-making," as opposed to "worldmirroring," feature of religious images reflects the philosophy shared by visual culture theorists like W. J. T. Mitchell and Christopher Pinney, who acknowledge that images are not mere reflections of the social, but are in fact constitutive of it (Mitchell, 2004, p. xv; Pinney, 2004).

In the campaign, the darshanic gaze functions as an instrument to capture the attention of the audience. The images explicitly render the divine feminine as susceptible to violence and would suggest that the cosmos-animating power of the Goddesses (shakti) is, in fact, ineffectual. A second, more insidious deduction implicit in a campaign against domestic violence is the unacknowledged involvement of the three Goddesses' male consorts that would suggest that Shiva, Vishnu, and Brahma are responsible for the Goddesses' battered states. However, the image takes care to remind the viewer that the violence is, after all, imaginary. Its artifice is not meant to be hidden; it is attested to and highlighted through the fourteen side-panel photographs adorning the left and bottom of the primary images of the battered Goddesses.

The panel images negotiate the atemporal effect that the artists aimed for; they pull the ad out of the nebulous ahistorical time that the image wishes to inhabit and position it within a time (the era of modern photography and computer-generated effect) and a place (the studio). The distinctions between reality and fiction, concrete and computer-generated objects, divine and human are rendered intentionally permeable and confusing. As if preparing for a protracted cultural debate and accusations of hurting religious sentiments, the ads deliberately display the preparatory process that transformed human women into images of Lakshmi, Durga, and Saraswati. Consequently, the viewer has a heightened awareness that the abused woman is not actually Lakshmi, but is a meta "Lakshmi" who has only taken on her appearance as a costume. Thus, the look of terror on Durga's makeup- and tear-streaked face, Saraswati's black eye, and Lakshmi's look of resignation are all mitigated by the presence of the photos that reveal the action "behind-the-scenes." While the images render impossible the potential for darshan, they also invite the viewer to engage in a second look. The juxtaposition of the divine and the abject, the real and the fictitious invites and delights in the double-take - the ability and demand to be seen once as a Goddess capable of bestowing her graces and again as an image of a woman posing as a recently-assaulted Goddess. Thus, the image 
doubly engages with the scopic drive, interlacing the divine gaze with the male gaze, positioning the Goddess in intersecting worlds of "to-be-looked-at-ness." ${ }^{3}$ Consequently, the divine gaze comes into competition with other looks that all vie to become the definitive gaze without ever settling the dispute.

It is clear, however, that the images rely overtly on the split between active/ male and passive/female that underscores the male gaze (Mulvey, 1975, p. 11). It is this split that catalyzed much of the negative reaction amongst feminist critics. The Goddess's lack of agency over her body constrains her ability to give darshan to the viewer, who not only retains an active gaze but also control over the Goddess herself. The text that exhorts the viewer to "pray" also offers a helpline for the would-be witness to report abuse, focusing the attention on the hypothetical future actions of the viewer, rather than the possible past actions of the Goddess.

Further, without the potential returned gaze of the deity, the onus of looking becomes the task of the viewer. The image capitalizes on the devotional imperative that expects the reciprocal gaze - the Goddess could give darshan if only she were not ensnared in an inauspicious moment. It is unclear whether she sees the viewer, but it is certain that the viewer is meant to witness her. Coorlawala (1996) remarks on this disparity between darshan and the male gaze, noting, "the inner activity of the devotee seeking communion is thus different from that of a voyeur in the darkened theaters of commercial films [...] Invisibility and non-relationship empower the voyeur with the capacity to name and manipulate mentally what is being projected on the screen, while remaining unmarked, thereby unseen" (p. 24). Through the literal and figurative violence of her inauspicious state, the Goddess's face becomes the object to be looked at but not a subject to look. In this sense, the reciprocal divine gaze is destabilized to make room for the act of witnessing.

This becomes particularly true once the images cross from the ocular field of Hindu visual culture into the promiscuous realm of internet memes destined for global audiences. Here, the act of bearing witness is one of the only intelligible acts of looking available to a non-Hindu audience. It is, in fact, the Abused Goddess campaign's ability to be "taken out of context" that contributes to its popularity. Further, outside of the "official narration of power," the images are free to enter the context of bearing witness that not only reflects,

3 This is not to suggest that the "male gaze" is never present within calendar art. However, a domestic violence public service announcement (particularly one that focuses on "married" Goddesses) interpellates the male viewer in a more specific way than the "standard" images of the Goddess that appear in the calendar art style. 
but has transformative potential. Following Frances Guerin and Roger Hallas, as the audience bears witness to the pain of the Goddess and, consequently, Indian (Hindu) women, the viewer-as-witness "[facilitates] the possibility of testimony" while also "sharing its burden" (2007, p. 11). The ability to share in that burden across religious, cultural, and geographical boundaries reflects the specific ethical orientation of "bearing witness" that supersedes Hindu theology and devotional practice, and renders any knowledge of either as incidental to the overall message of the image.

In addition to the exploitation of the almost-divine gaze and the act of witnessing accentuated by the male gaze, in the process of circulation the ads become open to a wider viewership and thus more varied ways of seeing. While not distinct from the male gaze, the "orientalizing gaze" was another point of departure for feminist critiques. The Feminist Wire's Sayantani DasGupta questions the appeal of the ads to non-Indian, and particularly, white feminist audiences: "I've realized that the positive reactions to these posters by feminist and progressive sites in the U.S. might have more to do with Orientalism [...] and a sisterhood of 'saving' than any position of global feminist solidarity [...] perhaps it's a case of 'white women saving brown women from brown men'” (DasGupta, 2013). DasGupta's invocation of Gayatri Spivak reveals the confusing nature of the images' circulation and highlights the potential for cultural miscommunication. She departs from other critics who bristle at the depiction of the violated Goddess-women, instead focusing on the "wrong" way of seeing. In this way, the act of looking itself conspires with the desecrating/ abusive act, rendering the Goddesses as double victims-once as the recipient of off-camera physical abuse, and again as Indian women subjected to the violent gaze of orientalism.

However, the ads, which feature Indian models and designers, are produced by an Indian ad agency, and beseech the viewer to call an Indian helpline, all seem to indicate that white feminists are not the primary audience for the campaign. The conservative depiction of the Goddess also suggests that the intended audience is one that has no interest in challenging either the patriarchal symbolic network in which her image is situated, or the paternalistic strictures that reduce women's agency. As Brinda Bose argues, the rhetoric of "saving" the Goddess, invoked even in the name "Save Our Sisters," suggests a much more restrictive approach to women's agency than the one the Goddess already embodies (Bose, 2013). Further, the invocation of calendar art fixes the ads in a culture of South Asian media popular across socioeconomic levels, but the use of English demands the attentions of the much smaller, though still considerable, English-educated middle class. The recycling of canonical forms of the Goddess lends itself to this idea since, as many critics have noted, the 
domesticated, Sanskritic, fair-skinned Goddesses signal a middle-class femininity that is "worth" saving in a way that regional, village, or low-caste Goddesses do not (Bose, 2013).

Still, DasGupta's wariness about the images' popularity raises critical questions about viewership and circulation. The "orientalizing gaze" that DasGupta argues characterizes the ads can only arise out of a global encounter. And while such a claim cannot be ignored when assessing the images' virality on the Internet, the idea of "global feminist solidarity" cannot be stressed enough. It is in fact this very notion, that there can be a global feminism, or universal rights, in which everyone can participate regardless of location or culture, that undergirds the very foundation of the campaign and allows the religious image to be reappropriated. The rhetoric of human rights-rights that function above all cultural and religious identities-binds together the gaze mechanisms of the camera, the viewer, and the devotional gaze of darshan to create a coherent image that is capable of being seen across geographic and cultural boundaries.

Adding to the difficulty of locating the intended viewership, Save the Children India reportedly distanced themselves from the ads with a statement on their website that disavowed the campaign and claimed the ads were never commissioned by their organization (Murphy, 2013). To further complicate the issue, though the campaign won numerous awards and was described as a "print ad," it doesn't appear to have ever been printed (Campaign Brief Asia, 2013). ${ }^{4}$

Save the Children India's disagreement over the ideology of the ads and the circumstances of their commission confuses the notion of an intended audience. Consequently, that the ads were produced in service of an organization that did not commission them and were addressed to an English-speaking Indian audience through the medium of popular devotional imagery provide insight into why the images circulated primarily on the Internet. It is likely that the images were designed to accrue awards and accolades, rather than to be printed for a wide audience. As such, that the images reached their apex of popularity through international news sites on the Internet is unsurprising. However, the sudden notoriety of the ads among varying groups attests to the affective intensity of images that breach the divide between the divine and human feminine.

4 Both the Huffington Post and Buzzfeed originally linked to the site ScoopWhoop, for the original location of the images. The original page on ScoopWhoop no longer functions, and though I attempted to find an originary source for the ads' online presence, it was predictably difficult, and I was unsuccessful. I was again unsuccessful in locating a print source for the images. Attempts to inquire with Taproot were similarly fruitless. 
As a collection of images that thrive on the crossing and confusing of multiple ways of seeing, the ads highlight the power that images wield to coalesce, fabricate, and disrupt identities. The ads capitalize on modern distinctions of private and public, positioning religious praxis as personal and, consequently, less relevant to the the greater social issue of gendered violence. It is capable of being commented on, utilized, and violated in service of a "universal" point, but it is not eligible to make comments about the public sphere. Still, the images highlight the permeability of disparate modes of seeing through the deliberate engagement with and departure from aesthetic conventions. Furthermore, the global circulation of the images encourages the crossing and confusions of multiple "looks" that all contribute to the "new visual experience" the creators hoped to achieve. It is through the violent collision of these disparate ways of seeing that we witness the production of an unsettling affect rendered across the body of the Goddess-women: shame.

The affect of shame performs a double function within the Abused Goddess images - it renders public the private humiliation of violence, and in doing so, it shames the viewer who has failed to intervene. The appearance and feeling of shame in the ads supplants all other viewing experiences (such as darshan) and renders the ads efficacious in a non-ritual, secular setting. This is significant, because to discuss shame in the context of images that cross geographic and cultural boundaries is to discuss the translatability of affective states. Much of the scholarship reflecting on the cultural and political mechanisms of shame has emerged out of queer theory since the 1990s, focusing primarily on North American and European subjects. ${ }^{5}$ The issue of whether "shame" in the United States reads as "shame" in India is a crucial component of the efficacy of the Abused Goddess images. Vinay Dharwadker (2015) has argued that the foremost treatise on the representation of emotion, the Nătya Śāstra, in fact shares in common strikingly similar paradigms to texts developed by Western authors nearly a millennium later. Although not an exact mapping, the study shows a compelling relationship between voluntary expressions of emotion used to delineate a codified aesthetic mode and involuntary reactions reflecting states of interiority. It is this precise tension in the artistic representation of interior emotional states that makes the Abused Goddess ads compelling and effective.

5 See Halperin and Traub 2008 and Munt 2007. 
Although there is overlap in the categorization of emotional states, it is also true that the cultural response to and ways of evaluating emotions is deeply variable. In a 2003 study, anthropologist Richard Shweder compared the North American concept of "shame" with the Orissan concept of lajya, frequently translated as shame into English. He argues that shame and lajya, though understood as interchangeable, are not, in fact, two expressions of the same concept. Shweder defines shame as, "the deeply felt and highly motivating experience of the fear of being judged defective. It is the anxious experience of either the real or anticipated loss of status, affection or self-regard that results from knowing that one is vulnerable to the disapproving gaze or negative judgment of others" (Shweder, 2003, p. 1115). However, lajya, he argues, may be best understood as "respectful self-restraint" or "graceful deference" (p. 1125). This is not only true for Orissan Brahmans, as equivalent terms in North Indian languages lajja, sharm, or the Sanskrit vrïda all convey affects associated with positive traits like humility and modesty. Vrïda, however, is also intimately connected with negative affects. What psychologist Silvan Tomkins terms "shame-humiliation" corresponds with an array of emotional states including vrị̈a (shame-embarrassment), nirveda (self-disprargement-humiliation), dainya (misery, enfeeblement), vishāda (dejection), and avahittā (dissumulation) (Dharwadker, 2015, pp. 1398, 1401). Consequently, the term "shame" in English is the equivalent of multiple interrelated emotions according to classical Indian theories of emotion.

Sara Ahmed argues that shame is never a strictly negative relation to another because shame is ambivalent (2004, p. 105). The Goddesses depicted do not register shame via any normative South Asian aesthetic convention associated with a "shameful" Goddess. The most famous, though disputed image of a "shamed" goddess is that of Kali, who sticks out and bites her tongue as a performative act of shame after trampling her consort Shiva in a fit of cosmosreordering rage. The story illustrates the Goddess's relationship to power and shame, since Kali, as mother of the universe, is uniquely poised to be able to destroy it, highlighting the ambivalent and fearsome power of shakti. Moreover, it is Kali's anger that caused her to go on a bloodletting frenzy until finally, biting her tongue, shame corralled her anger enough to control her power. Shame as the antidote to anger has a powerful tempering effect for women; in this sense it is neither bad nor disruptive-rather, shame is a mechanism for restoring the status quo (e.g., the reordering of gender relations, cosmic relations, caste relations).

This interpretation of the image, of course, runs counter to some Tantric interpretations in which shame is not present. One Tantric reading of the image is explicit about Shiva's subordinate position to Kali-a metaphor for the 
subordinate position of men to the cosmos-animating and life-giving power of the feminine. This Tantric view of the iconic image is telling in terms of how mainstream Hindu traditions have incorporated it into the Brahminical canon by means of shame. To be included in a patriarchal system, the clearly dominant Kali must be reinscribed to sustain dominant gender norms, rendering impotent the subversive potential of Tantra (Menon \& Shweder, 1994, p. 270). ${ }^{6}$ Within Brahmanical conceptions of womanhood, shame is not only the antidote to anger, but also to the unspoken and uniquely feminine attribute that is embedded within female rage-unmitigated power.

It is with this understanding that we may return to the Abused Goddess ads and their aesthetically and politically subversive use of shame. In the image of Durga, the Goddess wears a blank expression while subtly communicating a need for intervention. Here, the investment in realism begun by Ravi Varma and his printing press reaches a chilling climax in the graphic and naturalistic expressions of weariness, resignation, fear, and shame. Their naturalism bypasses conventional aesthetic expressions of shame such as the one worn by the bloodthirsty Kali who, according to normative interpretations of the image, displays her shame by sticking out her tongue. It is clear that the Goddesses feel a range of painful emotional and physical sensations, including the shame of seeing one's private troubles exposed to an audience, and particularly an audience whose relationship is predicated upon their omnipotent and protective power. Shame here is used in a number of ways-the shame of a powerless being to be without power, the shaming effect embedded within all acts of violence and, most importantly, the shame that impresses upon the audience who is compelled to witness and act. It indicts us, the viewer, for not only allowing the women to experience violence, but for allowing them to accompany that violence with feelings of shame. As Sally Munt has noted, shame has an anomalous "infective, contagious property" that binds together the recipient and bestower (2007, p. 24). Since shame involves a witness, this relationship is crucial to its functioning (Ahmed, 2004, p. 105). This act of witnessing produces a peculiar condition - that shame is intensified by others recognizing it as shame (p. 103).

That shame has the ability to "infect" the witness is what makes it a powerful affect. Shame operates within what Sara Ahmed has termed as "affective

6 Though their study was limited to Bhubaneswar, the normative, Brahminical reading of the image is not limited to Orissa, and I have heard similar accounts of the image told in Tamil Nadu and Rajasthan. Still, as Menon and Schweder illustrate, the shamed Kali is but one of many interpretations of the image, albeit an interpretation that is regarded as the most "culturally correct" (1994, p. 279). 
economies" - the network of emotions produced as effects of the circulation of objects that bind bodies together via the repetition of particular signs. As Ahmed argues, "emotions are crucial to the very constitution of the psychic and the social as objects, a process which suggests that the 'objectivity' of the psychic and social is an effect rather than a cause. In other words, emotions are not 'in' either the individual or the social, but produce the very surfaces and boundaries that allow the individual and the social to be delineated as if they are objects... it is the objects of emotion that circulate, rather than emotion as such" (pp. 10-11). Emotions, therefore, produce the boundaries between subject and object, self and other, by "impressing" themselves onto bodies.

Ahmed understands emotions as the crucial link between representation in public space and politics. In this context, shame is a powerful socio-political tool-the complex relationship between positive and negative affect crucial to shame (i.e., the disruption of interest and enjoyment and the ensuing desire to return to such a state of love) means that it has the potential to be regenerative and reintegrative. Shame, particularly public shame, can be understood as the failure to live up to normative ideals, to lose value in the gaze of an other, real or imagined (p. 107). The potential to be reintegrated into an ideal provides the mobilizing thrust of shame, though Ahmed is careful to note that reintegration is only possible when shame is understood to be an impermanent condition (p. 107). Consequently, in the public sphere shame operates as a powerful mechanism that unites bodies in an effort to reintegrate into a normative ideal. Moreover, shame has the capacity to define the boundaries of the social itself, and therefore has the power to profoundly reorient normative ideals.

Ahmed's understanding of emotions as being crucial to the formation of the individual and the social is particularly relevant to the discussion of the Abused Goddess ads. That the images utilize the expectation of the dissolution of subject and object in the form of darshan is what makes the ads resonant. The violence of abuse and the shame that it produces render the possibility of darshan ironic - a violated Durga or Lakshmi displaying the abhay mudra cannot promote feelings of fearlessness or protection. Thus, rather than a calendar image circulating the bazaar, binding together worshippers, the ads circulate within the affective economy of shame, disrupting the potential for union with the divine. The ads not only foreground the vulnerability and helplessness of the Goddesses, but they also bestow the viewer with power in a relationship in which they would typically be subordinate.

Thus, the images further complicate the already messy relationship between Goddess-victim and worshipper-witness. The emphasis on the hypocrisy of the act of violence towards women highlights the double action of shame in the images. The Goddesses experience the shame of exposure, of having 
the humiliation of violence made emphatically public. And it is this shame borne by the Goddesses that is also meant to shame the viewer into action. The ads therefore retain a transformative function, though not at all like the transformation of the devotee-it is a transformation of the social world that is necessary. Darshan, then, is replaced by the act of witnessing. Following Guerin and Hallas, "within the context of bearing witness, material images do not merely depict the historical world, they participate in its transformation" (2007, p. 4). Shame, then, is a subversive mechanism of the image. Rather than restoring the status quo of normative gender politics in India, it seeks to reform them, albeit by gesturing towards women's divinity, rather than their humanity. The act of replacing the darshan of the divine with the witnessing of shame and humiliation is what gives the ads their emotional, political, and aesthetic vigor. Although there is no explicit call to action in the images or in the text that accompanies them, the desire to see and be seen by the divine is replaced by a vague imperative to help women by recalling their shared ontological nature with the Goddess. This itself is a potentially transformative act and demonstrates the disruptive potential of shame in the ads. Consequently, shame operates outside of a theological mechanism meant to restore power to a patriarchal order. It is instead an instrument of secular ethics predicated on the concepts of bodily autonomy and the disavowal of gender violence. The displacement of devotional imperatives with the conceptual framework of universal rights conveys both the ads' potential for global circulation and also illustrates the hybrid aesthetic of social justice and human rights-oriented Goddess imagery.

\section{5 \\ Toward a Secular Humanist Aesthetic}

The emphasis on human rights present within depictions of the Goddesswoman is one aspect of her image that distinguishes it from canonical religious imagery. In the ads, the human rights of the abused Goddess-woman are best understood within the framework of secular humanism that emphasizes autonomy and appeals to an individual's inherent self-worth. Codified in the aftermath of World War II, human rights, as defined by the Universal Declaration of Human Rights of 1948 (UDHR), is predicated on the "inherent dignity and of the equal and inalienable rights" of all people (United Nations General Assembly, 1948). With the enumeration of these rights the United Nations sought to protect human beings from threats to their agency as individuals. Historian Michael Ignatieff observes that as a concept, human rights exist to "adjudicate... 
conflicts, to define the irreducible minimum beyond which group and collective claims must not go in constraining the lives of individuals" (2000, p. 331).

Embedded within the discourse of human rights is the concept of the secular as synonymous with the inalienable rights that emphasize the value and significance of the individual in the face of institutions and groups that claim otherwise. A secular humanism predicated on the inherent rights of individuals would take precedence over any religious authority that made claims on an individual's agency. Returning to Ignatieff, "Human rights is a secular humanism: an ethics ungrounded in divine or ultimate sanction and based only in human prudence" (p. 340). Of course, the authority, applicability, and the very definition of human rights are all very much contested and the concept has been fraught since its inception. ${ }^{7}$ What is clear, however, is that human rights and secular humanism have been far-reaching and resonant enough ideas to have been adopted by many legal systems worldwide, including India (Appiah 2000, p. 107).

Thus, the message of human rights and social justice that emerges alongside the image of the Goddess-woman are the very ideas that make her image possible. As the manifestation of the paradoxical marginality and capability of the feminine, the shakti that the Goddess-woman embodies is itself at the nexus of the sacred and the secular. The framework of secular humanism makes her image possible by providing a context in which religion is present but not the dominant authority.

The mimetic adoption of secular humanist ethical values by religious groups has been precipitated by previous controversies that have erupted over depictions of Hindu goddesses. Kajri Jain writes of the Shiv Sena's defacement of Maqbool Fida Husain's paintings of nude Hindu goddesses in 2006, “...the affront to the icon must be channelled through the secular discourse of obscenity and a sacralisation of the law $[. .$.$] the forced re-harnessing of these$ images to a sacral frame is necessarily accompanied by a desacralisation of the icon, exposing the secret of the sacred (2010, p. 211). Following Durkheim, the exposed "secret of the sacred" asserts that it is "nothing but the embodiment of the community that holds it sacred" (2010, p. 211).

It is not an exact analogy, as the Shiv Sena's defacement of Husain's paintings operates in an "idiom of desecration" that is different from the calculated portrayal of Goddesses styled to look bruised and beaten. Still, the idiom of desecration that undergirds the Shiv Sena's vandalization is a useful analogy

7 See The Evolution of International Human Rights: Visions Seen, Lauren, Paul Gordon. Philadelphia: University of Pennsylvania Press, 1998. 
for viewing the Abused Goddess ads, for both involve a performance of transgression. Here, the transgression of the ads is on the part of the producers of the image, rather than the protestors. But within the image, the physical violence functions as an act of desecration. Like vandalizing the work of M. F. Husain, the desecrating act is here rendered on the faces of the three Goddesses. It is not the physical object itself that has been desecrated, but the inter-ocular field recalled by the image that is marked by imagined violence. It is not an act of desecration that results from external intervention, but rather the coherence of the image as one of devotion is violated by the same genre of violence which is stylized, deliberate, and emphatically in service of a "larger" point.

The defacement tactics employed by the Shiv Sena are performatively different than the verbal and written protests against the Abused Goddess ads, but they both utilize the rhetoric of the secular to legitimize their grievances. In protest of the ads, detractors contextualized them not as blasphemous, but as illogical. In the outcry from the Goa-based Hindu Janajagruti Samiti (HJS) the depiction of the battered Goddesses takes a backseat to a complaint about the singling out of Hindus. An excerpt from their website reads,

It is a known fact that non-Hindus too, are perpetrators of atrocities against women in India [...] This reeks of sheer anti-Hindu bias! Can these companies dare to denigrate pictures of figures revered in other religions [...] These Goddesses have been shown falling victim to the domestic violence. Women are given the same status as Goddesses in Bharat; however, the advertising agency claims that maximum instances of atrocities are committed only against Hindu women [emphasis added] (Hindu Janajagruti Samiti, 2013).

The HJs' reaction to the ads reveals the way in which the images traverse sacred and secular positions - the secular humanist values that "permit" a public display of non-canonical images of Goddesses are important enough in the civil discourse that their detractors must appeal to it even as they argue a charge of blasphemy. The HJs draws its primary complaint not from the Goddesses' desecration as such, but from the idea that their desecration is "unfair," as it indicts only Hindus and not all religions equally, as per a secularist logic. The implicit visual comparison made between divine and human bodies, as well as the explicit verbal comparison the ads make, violate the continuum of human and divine femininity by suggesting that they are always, constantly present within one another. Accordingly, the HJS argues that the ads violate an "obvious" logic, not that their religious sentiments supersede the rights of the ad agency. 
Here, the HJS is concerned with the promises of Indian secularism - that all religions be treated equally in the eyes of the state. This is revealing since, unlike in the case of M. F. Husain, the public outcry does not build its argument on the basis of who has the authority to produce, use, and circulate iconic Hindu images, but rather why the images diverge from the "standard" canon. The Abused Goddess campaign privileges social justice over the sacred in their use of the Goddess. That there exists an established tradition of iconicity in Hinduism and that it is the majority religion in India make it a practical vehicle for delivering a message that is, ostensibly, non-sectarian. As such, the image's utilization of specifically Hindu iconic images is secondary to the concerted effort made to transcend religion by suggesting that domestic violence is a problem that supersedes personal belief or practice. Within the ads, there exists an implicit reordering of the hierarchy of values with social justice being larger than, but still frequently carried out within, a distinct religious mode. As such, the principles of social justice are not beholden to religious authority and can appropriate the sacred in service of secular humanist ethics.

\section{Conclusion}

In the age of the digital reproduction, virality, and spectacular images, is a "successful" image one that captures the attention of a large audience or one that communicates a message that spurs action? It is not a rhetorical question, since at least one of the features, if not failures, of the image is its lack of a clear audience and specific message. As a campaign to reduce domestic abuse, barring reception analysis of the images, it is impossible to know whether it contributed to a reduction in violent behavior towards women. However, as we have seen, for many devotees the abuse of women and the worship of Goddesses does not represent a hypocrisy. Rather, the "discrepancy" exposes their shared nature (shakti) and their differing relationships with that very nature. That women are powerful does not necessitate bowing to that power, it may very well reinforce the notion that power-and the women who wield itshould be restrained at all costs.

Herein lies the risk of the Goddess-woman hybrid: she can be so powerful that those around her do not acknowledge her humanity, but so human that she is unable to access the pervasive power of the Goddess. This is the uncomfortable space that the Abused Goddess ads inhabit. The ads share in common with other depictions of the Goddess-woman an approach to the 
female body that construes it as a cipher with which a range of topics can be elucidated. The Abused Goddess ads, however, are much more concerned with the female body as acted upon by men, rather than the Goddess as an agent herself. The mechanism of shame, the act of bearing witness, and the demand for justice create a sympathetic, rather than empathetic relationship with the Goddess-woman.

The ads depict a relationship that least lends itself to an empathetic response and that requires the least amount of relatability and the most amount of distance-a subservient devotee and an all-powerful deity. The ads speak from a position of witnessing, not of experiencing. The shame the viewer feels is not the shame that the Goddess-woman endures. Consequently, the images create affective distance rather than proximity. The ads create more distance between viewer and object - the opposite of both darshan and the posters. In the ads, the sympathetic gaze is the secularizing gaze of human rights-it is saving a passive victim as opposed to acknowledging the power inherent within her. Simultaneously, the visual effects and emotional rhetoric of shame reconfigure the images as a novel and politically subversive use of devotional imagery. It is this codification of secular humanist aesthetics that remains one of the campaign's most lasting triumphs.

\section{References}

"Abused Goddesses": Perversion or Persuasion? (2013, December 13). World Religion News. Retrieved from https://worldreligionnews.wordpress.com/2013/12/13/abusedgoddesses-perversion-or-persuasion.

Ahmed, S. (2004). The Cultural Politics of Emotion. New York: Routledge.

Appiah, K.A. (2001). Grounding Human Rights. In: A. Gutman, ed., Human Rights as Politics and Idolatry. Princeton, New Jersey: Princeton University Press, pp.101-116.

Bose, B. (2013, September 11). No More Goddesses, Please. Bring in the Sluts. Open Magazine. Retrieved from http://www.openthemagazine.com/article/arts-letters/ no-more-goddesses-please-bring-in-the-sluts.

Campaign Brief Asia. (2013, March 21). Taproot India Top All Agencies at AdFest 2013 Taking Out the Agency of the Year Gong. Retrieved from http://www.campaignbriefasia.com/2013/03/taproot-india-top-all-agencies.html.

Coorlawala, U.A. (1996). Darshan and Abhinaya: An Alternative to the Male Gaze. Dance Research Journal 28, (1), pp. 19-27.

DasGupta, S. (2013, September 12). Abused Goddesses, Orientalism and the Glamorization of Gender-Based Violence. The Feminist Wire. Retrieved from http://www .thefeministwire.com/2013/og/abused-goddesses. 
Dharwadker, V. (2015). Emotion in Motion: The Nātyashāstra, Darwin, and Affect Theory. Publications of the Modern Language Association of America 130 (5), pp. 1381-1404.

Edoho-Eket, N. (2016). The Mortal Divine: The Goddess, Women, and Power in South Asian Feminist Posters. Paper presented at the Annual Conference on South Asia, Madison, WI.

Edoho-Eket, N. (2018). \#Mood: When the Goddess Becomes a Woman on Social Media. Paper presented at the Conference on the Study of Religion in India, Davis, CA.

Erhlich, R.S. (2013, September 13). Abused Hindu Goddesses Recall Violence Against Women. The Washington Post. Retrieved from https://www.washingtonpost.com/ national/on-faith/abused-hindu-goddesses-recall-violence-against-women/2013/ og/13/def56fi6-1c9f-11e3-8oac-96205cacb45a_story.html?utm_term=.6d89ab5a863c.

Erndl, K.M. (2000). Is Shakti Empowering for Women? Reflections on Feminism and the Hindu Goddess. In: A. Hiltebeitel and K.M. Erndl, eds., Is the Goddess a Feminist? The Politics of South Asian Goddesses. Sheffield, England: Sheffield Academic Press, pp. 91-103.

Gonda, J. (1969). Eye and the Gaze in the Veda. Amsterdam: North Holland Publishing Company.

Guerin, F., and. and Hallas, R., eds. (2007). The Image and the Witness: Trauma, Memory and Visual Culture. New York: Wallflower Press.

Gross, R.M., (2000). Is the Goddess a Feminist? In: A. Hiltebeitel and K.M. Erndl, eds., Is the Goddess a Feminist? The Politics of South Asian Goddesses. Sheffield, England: Sheffield Academic Press, pp.104-112.

Halperin, D.M. and Traub, V., eds. (2009). Gay Shame. Chicago: University of Chicago Press.

Hindu Janajagruti Samiti. (2013, September 12). Protest: “Abused Goddesses" Campaign Condemning Domestic Violence Denigrate Hindu Deities. Hindu Janajagruti Samiti. Retreived from http://www.hindujagruti.org/news/17352_abused-goddesses -campaign-denigrate-hindu-deities.html.

Ignatieff, M. (2000, April 4-7). I. Human Rights as Politics, II. Human Rights as Idolatry. Presentation at The Tanner Lectures on Human Values. Princeton, New Jersey.

Jain, K. (2007). Gods in the Bazaar: The Economies of Indian Calendar Art. Durham, NC: Duke University Press.

Jain, K. (2010). Taking and Making Offence: Husain and the Politics of Desecration. In: M.F. Husain \& and S. Ramaswamy, eds., Barefoot Across the Nation: Maqbool Fida Husain and the Idea of India. New York: Routledge, pp. 198-212.

Jha, R. (2013, September 5). India's Incredibly Powerful "Abused Goddesses" Campaign Condemns Domestic Violence. Buzzfeed. Retrieved from https://www.buzzfeed .com/regajha/indias-incredibly-powerful-abused-goddesses-campaign condemn?utmterm=.xiN2zW7mv\#.tcdpkR576. 
Jha, Praneta. (2013, September 10). Abused or Not, Women Are Not Goddesses. Hindustan Times. Retrieved from https://www.hindustantimes.com/art-and-culture/ abused-or-not-women-are-not-goddesses/story-crcegadEhUagpZBtNg3VYP.html.

Khanna, M. (2002). The Goddess-Woman Equation in Sāata Tantras. In: D.S. Ahmed, ed., Gendering the Spirit: Women, Religion \& the Post-colonial Response, New York: Zed, pp. 35-59.

Menon, U. and Shweder, R.A., eds. (1994). Kali's tongue: Cultural Psychology and the Power of Shame in Orissa, India. Emotion and Culture: Empirical Studies of Mutual Influence, pp. 241-284.

Mitchell, W.J.T. (2005). What Do Pictures Want? The Lives and Loves of Images. Chicago: University of Chicago Press.

Mulvey, L. (1975). Visual Pleasure and Narrative Cinema. Screen 16 (3), pp. 6-18.

Murphy, T. (2013, September 16). Save the Children India Distances Itself from Controversial Abuse Campaign. Humanosphere. Retrieved from http://www.humanosphere .org/basics/2013/og/ save-the-children-india-distances-itself-from-controversial -abuse-campaign/.

Munt, S.R. (2017). Queer Attachments: The Cultural Politics of Shame. London: Routledge. Pinney, C. (2004). "Photos of the Gods": The Printed Image and Political Struggle in India. New Delhi: Oxford University Press.

Roy, V. (2016, June 2). Goddess Under Attack. The Hindu. Retrieved from http://www .thehindu.com/features/the-yin-thing/goddess-under-attack/article5129205.ece.

Taproot India. Brand: Save Our Sisters (sTCI). Coloribus. Retrieved from http://www .coloribus.com/adsarchive/prints/save-our-sisters-abused-goddess-2-17889905/.

Shweder, R.A. (2003). Toward a Deep Cultural Psychology of Shame. Social Research:An International Quarter 70 (4), pp. 1100-1129.

Shukla, S. (2013, November 11). Remember the Goddess Within Us. The Huffington Post. Retrieved from https://www.huffingtonpost.com/suhag-a-shukla-esq/remember -the-goddess-with_b_3899907.html.

United Nations General Assembly. (1948) Universal Declaration of Human Rights. Retrieved from http://www.un.org/en/universal-declaration-human-rights. 